main components of coal. If, however, in future by the combination of petrological and analytical data, the physical and chemical properties of the small units of the coal complex can be ascertained, the composite value of the fuel will be assessed with much greater accuracy than is possible at present. What may, therefore, appear to-day as a somewhat academic problem, may to-morrow have a very definite effect on practical coal politics. The coal producer, knowing that he can only sell the coal which he happens to find in his pit, usually stands aloof from attempts to codify coals in anything but a 'use' classification. In Great Britain, even schemes for grading coal by size and freedom from ash and moisture have so far been regarded with disfavour. The modern requirements of the industrial consumer, however, make more rigorous demands on the properties of coal used in his processes and indicate the necessity of defining these in terms different from the nondescript 'Derby Brights' beloved by the British householder in the past.

1 "Fuel in Science and Practice", Jan. 1935, 14, 4-13.

${ }^{2}$ Copies can be obtained from Dr. M. C. Stopes, Norbury Park, nr Dorking, England.

\title{
Obituary
}

\section{Prof. Ganesh Prasad}

W E regret to announce that Prof. Ganesh Prasad died on March 9, with unexpected suddenness. Born in Ballia, a small town in the United Provinces, India, on November 15, 1876, Prasad took the D.Sc. degree of the University of Allahabad at the age of twenty-two years, and then studied at Cambridge and Göttingen as a Government of India scholar. After serving for ten years as a professor of mathematics in his native province on his return from Europe, in 1914 he joined the University of Calcutta as the Ghosh professor of applied mathematics. $\mathrm{He}$ left this post four years later to join the Benares Hindu University as its University professor, but came back to Calcutta in 1923, this time as the Hardinge professor of pure mathematics, which post he occupied until the time of his death. While he was in the Benares Hindu University, he was also the principal of the Arts and Science College for about two years.

Prof. Prasad was the first in India to create a school of mathematical research. Many of the papers on mathematics published by young Indian investigators in the last twenty years bear an acknowledgment of indebtedness to him for guidance and help. $\mathrm{He}$ founded the Benares Mathematical Society in 1918, and was its life-president. He had been for many years the president also of the Calcutta Mathematical Society.

One of the earliest contributions made by Prof. Prasad was his dissertation entitled "The Constitution of Matter and Analytical Theories of Heat" (1903), in which he dealt with the difficulty of interpreting differential coefficients when the molecular constitution of matter is taken into account. His papers on applied mathematics, published in various journals, dealt likewise with problems in which he skilfully applied his knowledge of the theory of functions of a real variable to potential problems in which the differential coefficients became infinite or did not exist. His later researches were on the theory of Fourier series and other branches of the theory of functions of a real variable. At the time of his death he had in hand the completion of a long memoir on "The Expansion of Zero", which he had promised to contribute to the first issue of the journal of the newly created National Institute of Sciences, India, of which he was a member of council.

Prof. Prasad was well known as a teacher, and his textbooks on the differential and integral calculus are still in use in many Indian universities. His Patna University readership lectures on "The Place of Partial Differential Equations in Mathematical Physics" were published in 1924, and since 1928 he had devoted a good deal of his time to the writing of books on higher mathematics and on the history of the subject.

Prof. Prasad was much loved and admired by his numerous pupils, to whom he was always a source of great inspiration. He was a man of wonderfully simple habits, and remarkable energy and powers of endurance. He had a marvellous memory. When he was a principal-to mention but one examplehe recognised all the students (more than one thousand in number) and remembered not only their names but also numerous details about them. Gorakr Prasad.

\section{Dr. Shepherd Dawson}

By the death of Dr. Shepherd Dawson on March 26 at a relatively early age, experimental psychology in Great Britain has suffered a great loss. For a period of many years, his experimental contributions have been published in the technical journals (mostly in the British Journal of Psychology). All have been marked by careful attention to the requirements of scientific method. In later years his attention was directed towards the statistical problems of psychology, and a few years ago he published a book on statistics.

Shepherd Dawson's earliest published work on various problems of vision already showed his quality as an accurate and painstaking experimentalist. After he succeeded H. J. Watt as principal lecturer in psychology, logic and ethics at Jordanhill Training College, Glasgow, he did not lose his interest in experimental research. At meetings of the British Association he had generally some original investigation to report. Probably the best known of his later contributions to experimental psychology was his 